\title{
EFEKTIVITAS PENAMBAHAN PROLACZYME PADA PAKAN KOMERSIAL TERHADAP PERTUMBUHAN IKAN NILA (Oreochromis niloticus)
}

\author{
(The Effectiveness Of Prolaczyme Addition To The Commercial Feed Fish On Nile Tilapia's \\ (Oreochromis Niloticus) Growth Performance)
}

\author{
Tania Serezova Augusta ${ }^{1}$, Deby Setyani ${ }^{2}$, Kristina $^{3}$ \\ ${ }^{1,2}$ Fakultas Perikanan Universitas Kristen Palangka Raya \\ Email: ${ }^{1}$ taniaserezova@gmail.com; ${ }^{2}$ debysetyani@gmail.com \\ ${ }^{3}$ Fakultas Peternakan Universitas Kristen Palangka Raya \\ Jalan RTA. Milono Km. 8,5 Palangka Raya \\ Email: ${ }^{3}$ kristina.pky22@gmail.com
}

Article Submitted: $12-09-2020$

Article Accepted : 25-09-2020

\begin{abstract}
The utilization of effective and efficient feed given for growth is an indicator of successful fish cultivation. Enzyme activity is one of affects the growth rate of fish factors. Therefore, it is expected the addition of the enzyme of feed increases the growth and utilization of Nile Tilapia's (Oreochromis Niloticus) significantly. The study was to determine the effectiveness of prolaczyme dosage addition to the commercial feed fish on Nile tilapia's (Oreochromis niloticus) growth performance. This research was conducted from June to July 2020 on Palangka Raya, Central Kalimantan. This study used completely randomized method 3 treatments and 3 repetitions, tilapia's fish seeds size $2.07-2.23 \mathrm{~cm}$ with a container (15 fish/basin) water volume of 50 liters, and 1 month maintenance time. The results of the calculation of absolute length growth at the end of the study showed that treatment $\mathrm{C}$ was higher $5.30 \mathrm{~cm}$ compared to treatment A was $3.71 \mathrm{~cm}$ and treatment B was $4.59 \mathrm{~cm}$. The results of the calculation of the absolute weight growth at the end of the study also showed that treatment $\mathrm{C}$ was higher at $2.41 \mathrm{gr}$ compared to treatment A was 0.99 grand treatment B was 1.52 gr. The FCR value shows that treatment $\mathrm{C}$ worth 1.77 is better than treatment $\mathrm{A}$ worth 3.33 and treatment $\mathrm{B}$ worth 2.44 . The results of water quality temperature, $\mathrm{pH}$, and dissolved oxygen (DO) both at the beginning and at the end of the study showed a range that tilapia could still tolerate for growth.
\end{abstract}

Keywords: Growth, nile tilapia's, prolaczyme, feed

\section{PENDAHULUAN}

Nila (Oreochromis niloticus) di Indonesia merupakan salah satu ikan air tawar yang memiliki nilai ekonomis tinggi dan merupakan komoditas penting dalam bisnis ikan air tawar dunia, cara budidaya yang relatif mudah, rasa yang disukai banyak orang, harga yang relatif terjangkau dan toleransi terhadap lingkungan yang lebih tinggi. Peningkatan padat tebar hingga mencapai daya dukung maksimum akan menyebabkan pertumbuhan ikan menurun. Peningkatan padat penebaran akan diikuti dengan peningkatan jumlah pakan, sisa metabolisme tubuh, konsumsi oksigen, dan dapat menurunkan kualitas air (Diansari, 2013).

Mengingat ukuran lambung yang kecil pada ikan Nila (Kabaryk dalam Tengjaroenkul, 2000), dimana pencernaan secara enzimatis terjadi, dan pemberian pakan buatan, dibutuhkan ekstra enzim yang 
ditambahkan pada pakan untuk membantu memecah polimer sehingga dapat memperlancar absorbsi nutrisi pakan pada proses pencernaan.

Pakan merupakan salah satu unsur penting dalam kegiatan budidaya yang menunjang pertumbuhan dan kelangsungan hidup ikan budidaya. Pakan terdiri dari pakan alami dan pakan buatan. Pakan buatan adalah campuran dari bahan-bahan pakan yang memiliki kandungan nutrisi yang berbeda-beda. Hal inilah yang menyebabkan pentingnya pakan sehingga perlu dilakukan penelitian untuk memperbaiki nilai nutrisi pakan, nilai nutrisi pada pakan pada umumnya dilihat dari komposisi zat gizi dan berapa komponen nutrisi yang penting dan harus tersedia dalam pakan, antara lain : protein, lemak, karbohidrat, dan vitamin. Untuk memperbaiki nilai nutrisi pakan yaitu dengan menambahkan enzim pada pakan.

Enzim merupakan salah satu aspek biologis yang penting untuk diamati karena sangat berhubungan dengan pemanfaatan pakan dan pertumbuhan pada ikan. Oleh karena itu diharapkan penambahan enzim pada pakan dapat meningkatkan pertumbuhan dan pemanfaatan pakan secara signifikan pada ikan nila (Oreochromis niloticus). Hal inilah yang melatarbelakangi penelitian pemberian enzim kompleks pada pakan ikan dengan persentase kandungan protein $(39 \%)$ di dalamnya. Jenis pakan ikan sudah terbiasa digunakan di kalangan petani ikan nila di wilayah Kalimatan
Tengah, khususnya di daerah Kota Palangka Raya.

\section{METODE PENELITIAN}

Penelitian ini dilaksanakan pada bulan Juni sampai Juli 2020, di dalam baskom sebanyak 9 (sembilan) buah. Metode pelaksanaan kegiatan penelitian ini menggunakan Rancangan Acak Lengkap dengan 3 perlakuan dan 3 ulangan, dengan ikan uji benih ikan nila ukuran 2,07-2,23 cm dengan wadah pemeliharaan baskom (15 ekor/baskom) dengan volume air 50 liter, dan masa pemeliharan 1 bulan.

Perlakuan A : Pakan komersial tanpa pemberian enzim.

Perlakuan B : Pakan komersial dengan penambahan dosis enzim 5 gram $/ \mathrm{kg}$ pakan

Perlakuan C : Pakan komersial dengan penambahan dosis enzim10 gram/kg pakan

\section{HASIL DAN PEMBAHASAN}

\section{Pertumbuhan Ikan Nila}

Pertumbuhan ikan nila yang diamati selama penelitian inimeliputi pertumbuhan panjang mutlak, pertumbuhan berat mutlak, dan Food Convertion Ratio (FCR). Dari hasil penelitian selama 1 bulan, menunjukkan bahwa ikan nila yang dipelihara mengalami pertumbuhan pada masing-masing perlakuan. Grafik pertumbuhan panjang dan berat ikan nila dapat dilhat pada Gambar 1. 


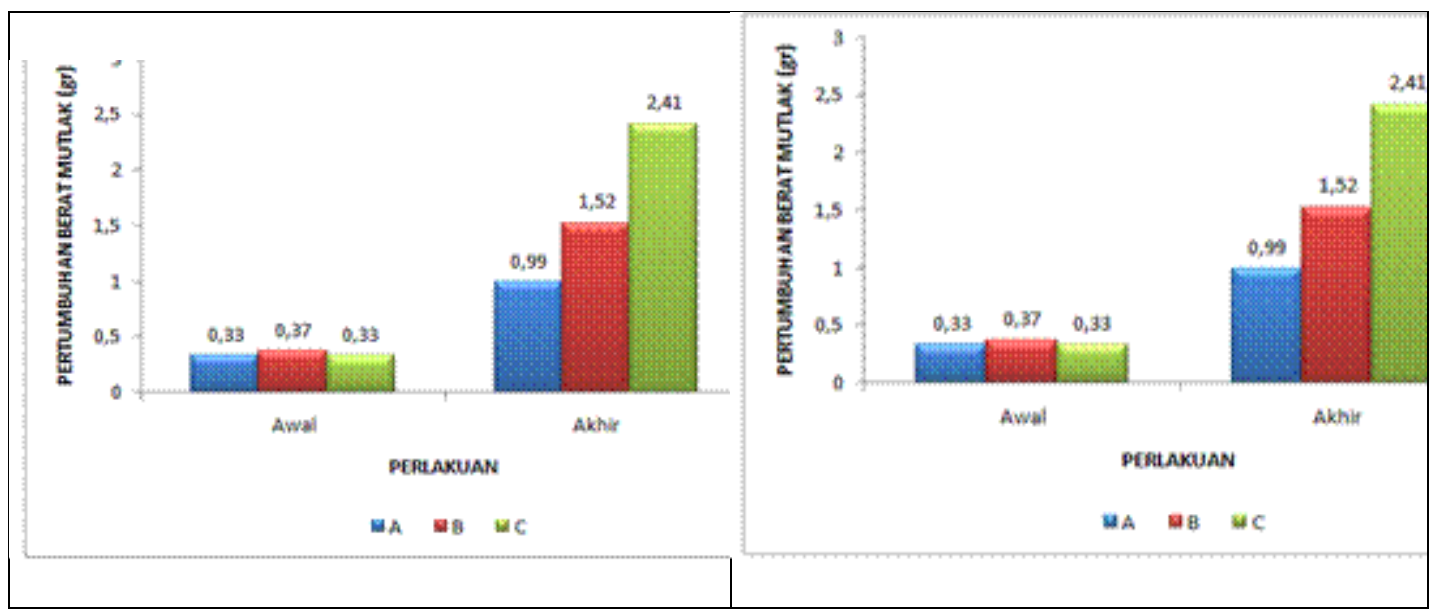

Gambar 1. Grafik Pertumbuhan Panjang dan Berat Ikan Nila

Hasil penelitian menunjukkan adanya pertumbuhan panjang mutlak pada masing-masing perlakuan. Pertumbuhan panjang mutlak pada Perlakuan $\mathrm{C}$ yaitu pakan komersial dengan penambahan dosis enzim $10 \mathrm{gram} / \mathrm{Kg}$ pakan menunjukan nilai yang lebih tinggi yaitu sebesar $5,30 \mathrm{~cm}$ dibandingkan 2 (dua) perlakuan yaitu Perlakuan A sebesar 3,71 cm dan Perlakuan B sebesar 4,59 cm. Berdasarkan uji Duncan $5 \%$, menunjukkan bahwa pertumbuhan panjang mutlak memberikan pengaruh yang berbeda nyata pada masing-masing perlakuan.Pertumbuhan sebagai pertambahan dalam volume dan berat dalam waktu tertentu (Handajani dan Widodo, 2010). Secara garis besar, pakan dipergunakan untuk kelangsungan hidup, kelebihannya untuk pertumbuhan. Apabila pakan hanya cukup untuk pemeliharaan tubuh (maintance), maka bobot ikan akan tetap (Halver, 1972). Kehadiran enzim dalam pakan dapat membantu dan mempercepat proses pencernaan, sehingga nutrien dapat cukup tersedia untuk pertumbuhan. Penambahan komposisi enzim khususnya enzim pencernaan seperti enzim protease, lipase dan amilase mampu menghidrolisis protein menjadi unsur-unsur yang lebih sederhana yaitu peptida hingga asam amino sehingga meningkatkan pemanfaatan protein pakan oleh tubuh ikan nila. Penambahan komposisi enzim dengan dosis berbeda diharapkan dapat memaksimalkan kandungan nutrisi pada pakan buatan sehingga protein majemuk yang terkandung dalam pakan buatan mampu diserap secara maksimal oleh ikan. Secara umum, enzim menghasilkan kecepatan, spesifikasi, dan kendali pengaturan terhadap reaksi dalam tubuh. Enzim berfungsi sebagai katalisator, yaitu senyawa yang meningkatkan kecepatan reaksi kimia (Kusumadjaja dan Dewi, 2005).

Hasil perhitungan pertumbuhan berat mutlak pada akhir penelitian menunjukkan bahwa perlakuan $\mathrm{C}$ lebih tinggi yaitu sebesar 2,41 gr dibandingkan dengan kedua perlakuan lainnya masing-masing yaitu pada perlakuan A sebesar 0,99 gr dan perlakuan B sebesar 1,52 gr.Berdasarkan uji Duncan $5 \%$, menunjukkan bahwa pertumbuhan berat mutlak pada perlakuan A dan perlakuan B tidak memberikan pengaruh yang nyata, sedangkan pada perlakuan $\mathrm{C}$ memberikan pengaruh yang nyata pada kedua perlakuan lainnya.Meskipun pada uji statistik pada perlakuan A dan B tidak menunjukkan perbedaan yang nyata namun pada perlakuan $\mathrm{C}$ memberikan pengaruh yang berbeda nyata pada kedua perlakuan yang lain dimana perlakuan C yaitu 2,41 gr lebih baik dibandingkan perlakuan A yaitu 1,52 gr dan perlakuan B yaitu 0,99 gr . Hal ini menunjukkan benih ikan nila dapat memanfaatkan pakan yang diberikan dengan 
baik karena didukung oleh aktivitas enzim. Hal ini sesuai dengan pendapat Huet (1970), bahwa laju pertumbuhan yang tinggi berkaitan dengan efisiensi pakan yang tinggi pula. Efisiensi pakan yang tinggi menunjukkan penggunaan pakan yang efisien, sehingga hanya sedikit zat makanan yang dirombak untuk memenuhi kebutuhan energi dan selebihnya digunakan untuk pertumbuhan.

Nilai FCR pemeliharaan ikan nila selama penelitian diperoleh bahwa perlakuan $\mathrm{C}$ lebih baik yaitu senilai 1,77 dibandingkan dengan perlakuan A senilai 3,33 dan perlakuan $B$ senilai 2,44. Berdasarkan uji Duncan $5 \%$, menunjukkan bahwa Food Convertion Ratio (FCR) tidak memberikan pengaruh yang berbeda nyata pada masing-masing perlakuan, namun jika dilihat dari hasil statistik bahwa FCR paling rendah terdapat pada perlakuan $\mathrm{C}$ senilai 1,77 sedangkan FCR pakan tertinggi terdapat dalam perlakuan A yaitu senilai 3,33 diikuti perlakuan B yaitu senilai 2,44. Semakin rendah nilai FCR maka semakin baik pula ikan memanfaatkan pakan sebagai pertumbuhannya. Karena dalam pengertian FCR senilai 1 berarti 1 (satu) kg pakan menghasilkan 1 (satu) daging. Rendahnya FCR pada perlakuan $\mathrm{C}$ diduga karena perlakuan dengan pemberian enzim lebih baik dibandingkan dengan yang tanpa perlakuan enzimatis, sehingga mempengaruhi kualitas pakan buatan. Menurut Halver (1972) bahwa semakin tinggi nilai efisiensi pakan memberikan gambaran bahwa kualitas pakan semakin baik. Hal ini diduga karena nutrisi pada pakan $\mathrm{C}$ memiliki komposisi asam amino yang sesuai dengan asam amino yang sama dengan tubuh ikan mempunyai nilai nutrisi yang tinggi sehingga pembuatan pakan dapat di formulasikan dari beberapa sumber protein untuk mensimulasi komposisi asam amino yang sesuai dengan asam amino tubuh ikan (Anonim, 2009). Hal serupa juga terlihat bahwa FCR pada perlakuan $\mathrm{C}$ berkorelasi dengan pertumbuhan ikan nila. Menurut Sari et al (2013) bahwa kecernaan pakan berkorelasi dengan efisiensi pemanfaatan pakan. Semakin besar nilai suatu efisiensi pakan, maka semakin tinggi pula tingkat pertumbuhannya.

\section{Kualitas Air}

Hasil pengamatan kualitas air menunjukkan tidak ada perubahan yang signifikan di awal penelitian sampai di akhir penelitian. Perubahan kualitas air yang mengalami perubahan hanya terlihat pada oksigen terlarut (DO) pada masing-masing perlakuan khususnya di akhir penelitian. Hasil Pengukuran kualitas air selama penelitian dapat dilihat pada Tabel 1 .

Tabel 1. Kualitas Air Pemeliharan Ikan Nila

\begin{tabular}{lcccccc}
\hline & \multicolumn{6}{c}{ Rataan dan Kisaran Nilai } \\
\cline { 2 - 7 } Parameter & \multicolumn{7}{c}{ Perlakuan } \\
\cline { 2 - 7 } & A & B & C & A & B & Ckhir Penelitian \\
\cline { 2 - 7 } & 25 & 25 & 25 & 24,13 & 24 & 24 \\
\hline Suhu (oC) & 6 & 6 & 6 & 6 & 5,66 & 6 \\
pH & 6,25 & 6,38 & 6,14 & 4,9 & 5,46 & 4,72 \\
DO (mg/L) & & &
\end{tabular}

Berdasarkan hasil pengamatan kualitas air yang diperoleh bahwa suhu pada saat awal penelitian dan akhir penelitian berkisar antara $24-25{ }^{\circ} \mathrm{C}$. Rendahnya suhu diakibatkan penelitian dilakukan di baskom yang lokasinya berada di dalam rumah sehingga tidak langsung terkena sinar matahari langsung. Namun suhu tersebut masih berada dalam batas yang layak bagi pertumbuhan ikan nila. Adapun kualitas air media pemeliharaan ikan nila sesuai Badan 
Standarisasi Nasional (2009) harus memiliki rentang suhu $23^{\circ} \mathrm{C}$ hingga $30^{\circ} \mathrm{C}$.

Nilai $\mathrm{pH}$ pada saat penelitian baik pada awal penelitian dan akhir penelitian pada masing-masing perlakuan berkisar antara 5,66 - 6. Menurut Popma dan Masser (1999) menyatakan bahwa umumnya ikan nila dapat hidup pada kisaran $\mathrm{pH} 5$ - 10, tetapi untuk pertumbuhan terbaik pada kisaran $\mathrm{pH} 6-9$. Hal ini menunjukkan $\mathrm{pH}$ air masih layak untuk kelangsungan hidup dan pertumbuhan ikan nila.

Nilai oksigen terlarut (DO) pada saat penelitian pada awal penelitian berkisar 6,14 - 6,38 mg/L. Sedangkan pada akhir penelitian berkisar 4,72 - 5,46 mg/L. Perbedaan nilai oksigen terlarut (DO) pada awal dan akhir penelitian kemungkinan diakibatkan adanya makanan dan kotoran ikan yang mengendap sehingga terbentuk bakteri pengurai yang berakibat adanya kompetisi oksigen baik ikan maupun bakteri pengurai di dalam tempat pemeliharaan. Menurut Andrianto (2005) bahwa kandungan oksigen terlarut yang baik untuk pertumbuhan dan perkembangan ikan nila sebesar 5 mg/L. Menurut Soderberg (2006) dalam Tran-Duy et al. (2008) DO minimum untuk nila sebesar 2,9 mg/L. Kisaran oksigen terlarut pada masing-masing perlakuan masih dalam kisaran toleransi bagi pertumbuhan ikan nila.

\section{KESIMPULAN}

Hasil perhitungan pertumbuhan panjang mutlak pada akhir penelitian menunjukkan bahwa perlakuan $\mathrm{C}$ lebih tinggi yaitu sebesar $5,30 \mathrm{~cm}$ dibandingkan dengan kedua perlakuan lainnya masingmasing yaitu pada perlakuan A sebesar $3,71 \mathrm{~cm}$ dan perlakuan B sebesar $4,59 \mathrm{~cm}$. Hasil perhitungan pertumbuhan berat mutlak pada akhir penelitian juga menunjukkan bahwa perlakuan $\mathrm{C}$ lebih tinggi yaitu sebesar 2,41 gr dibandingkan dengan kedua perlakuan lainnya masing-masing yaitu pada perlakuan A sebesar 0,99 gr dan perlakuan B sebesar 1,52 gr. Nilai FCR menunjukkan bahwa perlakuan $\mathrm{C}$ senilai 1,77 lebih baik dibandingkan perlakuan A senilai 3,33 dan perlakuan B senilai 2,44. Hasil pengukuran kualitas air yaitu suhu, $\mathrm{pH}$ dan oksigen terlarut (DO) baik pada awal dan akhir penelitian menunjukkan kisaran yang masih dapat ditoleransi oleh ikan nila untuk pertumbuhan.

\section{DAFTAR PUSTAKA}

Andrianto, T,T. 2005. Pedoman Praktis Budidaya Ikan Nila. Yogyakarta. $110 \mathrm{hlm}$.

Anonim. 2009. Pengembangan Teknologi Produksi Ikan Nila Unggul untuk Mendukung Program Ketahanan Pangan Nasional. http://repositori.bppt.go.id. Diakses pada tanggal 17 Juli 2020.

Badan Standarisasi Nasional(BSN). 2009. Produksi Ikan Nila (Oreochromis niloticus Bleeker) Kelas Pembesaran di Kolam Air Tenang. SNI 7550:2009. $12 \mathrm{hlm}$.

Diansari. 2013. Makanan Ikan. Penerbit : Penebar Swadaya, Jakarta. $190 \mathrm{hlm}$.

Halver, J.E. 1972. Fish Nutrition. Academic Press. London. New York. 713 pp.

Handajani, Widodo. 2010. Nutrisi Ikan. UMM Press. Malang.

Huet, M. 1970. Textbook of Fish Culture.

Kusumadjaja dan Dewi, 2005 Determination of Optimum Condition of Papain Enzyme From Papaya Var Java (Carica papaya). Indo. J. Chem. 5: 147-151.

Popma, T, Masser, M. 1999. Tilapia Life History and Biology. Southern 
Regional Aquaculture Center Publication Np. 283.

Sari, W.A.P, Subandiyono, Hastuti, S. 2013. Pemberian Enzim Papain Untuk Meningkatkan Pemanfaatan Protein Pakan dan PertumbuhanBenih Ikan Nila Larasati (Oreochromis niloticus Var). Journal of Aquaculture Management and Technology 2 (1) : 1-12.

Tengjaroenkul, 2000 Distribution of

\section{Intestinal Enzyme Activities Along}

The Intestinal Tract in $O$. niloticus. Aquaculture 182: 317-327.

Tran-Duy A, Schrama JW, Van Dam AA, Verreth JAJ. 2008. Effect of Oxygen Concentration and Body Weight on Maximum Feed Intake, Growth and Hematological Parameters of Nile Tilapia, Oreochromis niloticus. Aquaculture $275: 152-162$. 